University of Nebraska - Lincoln

DigitalCommons@University of Nebraska - Lincoln

6-2013

\title{
Size-Dependent Trophic Patterns of Pallid Sturgeon and Shovelnose Sturgeon in a Large River System
}

William E. French

Brian D.S. Graeb

Katie N. Bertrand

Steven R. Chipps

Robert A. Klumb

Follow this and additional works at: https://digitalcommons.unl.edu/usfwspubs

This Article is brought to you for free and open access by the US Fish \& Wildlife Service at

DigitalCommons@University of Nebraska - Lincoln. It has been accepted for inclusion in US Fish \& Wildlife Publications by an authorized administrator of DigitalCommons@University of Nebraska - Lincoln. 


\title{
Articles \\ Size-Dependent Trophic Patterns of Pallid Sturgeon and Shovelnose Sturgeon in a Large River System
}

\author{
William E. French,* Brian D.S. Graeb, Katie N. Bertrand, Steven R. Chipps, Robert A. Klumb
}

W.E. French, B.D.S. Graeb, K.N. Bertrand

Northern Plains Biostress Laboratory, Department of Natural Resource Management, South Dakota State University Brookings, South Dakota 57007

\section{S.R. Chipps}

U.S. Geological Survey South Dakota Cooperative Fish \& Wildlife Research Unit, Department of Natural Resource Management, South Dakota State University Brookings, South Dakota 57007

\section{R.A. Klumb}

U.S. Fish and Wildlife Service, Great Plains Fish and Wildlife Conservation Office, Pierre, South Dakota 57501

\begin{abstract}
This study compared patterns of $\delta^{15} \mathrm{~N}$ and $\delta^{13} \mathrm{C}$ enrichment of pallid sturgeon Scaphirhynchus albus and shovelnose sturgeon S. platorynchus in the Missouri River, United States, to infer their trophic position in a large river system. We examined enrichment and energy flow for pallid sturgeon in three segments of the Missouri River (Montana/North Dakota, Nebraska/South Dakota, and Nebraska/lowa) and made comparisons between species in the two downstream segments (Nebraska/South Dakota and Nebraska/lowa). Patterns in isotopic composition for pallid sturgeon were consistent with gut content analyses indicating an ontogenetic diet shift from invertebrates to fish prey at sizes of $>500-\mathrm{mm}$ fork length (FL) in all three segments of the Missouri River. Isotopic patterns revealed shovelnose sturgeon did not experience an ontogenetic shift in diet and used similar prey resources as small ( $<500-\mathrm{mm} \mathrm{FL})$ pallid sturgeon in the two downstream segments. We found stable isotope analysis to be an effective tool for evaluating the trophic position of sturgeons within a large river food web.
\end{abstract}

Keywords: pallid sturgeon; shovelnose sturgeon; stable isotopes; trophic position

Received: February 3, 2012; Accepted: March 7, 2013; Published Online Early: March 2013; Published: June 2013

Citation: French WE, Graeb BDS, Bertrand KN, Chipps SR, Klumb RA. 2013. Size-dependent trophic patterns of pallid sturgeon and shovelnose sturgeon in a large river system. Journal of Fish and Wildlife Management 4(1): 41-52; e1944687X. doi: 10.3996/022012-JFWM-013

Copyright: All material appearing in the Journal of Fish and Wildlife Management is in the public domain and may be reproduced or copied without permission unless specifically noted with the copyright symbol $\odot$. Citation of the source, as given above, is requested.

The findings and conclusions in this article are those of the author(s) and do not necessarily represent the views of the U.S. Fish and Wildlife Service.

*Corresponding author: Fren0104@umn.edu

\section{Introduction}

Knowledge of ontogenetic shifts in consumer diets is important for understanding factors that influence energy flow in aquatic food webs (Michelsen et al. 1994; Takimoto et al. 2002). The position of fish species within a food web is of interest to managers because trophic position of a consumer often has consequences for population dynamics such as growth and survival. Gut content analysis has traditionally been the basis for constructing food webs but may provide an incomplete picture of trophic structure because it offers only a snapshot of a consumer's diet. Conversely, stable isotope analysis (SIA) offers a time-integrated method of examining trophic relationships between consumers and their prey (Peterson and Fry 1987).

Stable isotope analysis provides information regarding trophic position of a consumer by examining ratios of $\delta^{13} \mathrm{C}$ and $\delta^{15} \mathrm{~N}$ isotopes incorporated into the consumer's tissue. Researchers commonly use stable $\delta^{13} \mathrm{C}$ ratios to determine energy sources in fishes. Depleted $\delta^{13} \mathrm{C}$ (i.e., more negative; lesser) values in fishes generally represent 
more pelagic (open water) or autochthonous (in-stream production) based food sources; whereas, more enriched (i.e., less negative; greater) values are characteristic of littoral/allochthonous (near-shore, out-of-stream production) based food sources (Peterson and Fry 1987). The stable $\delta^{15} \mathrm{~N}$ signature can indicate the trophic position, with an approximately 3.4\% increase in $\delta^{15} \mathrm{~N}$ signature and a $1.0 \%$ increase in $\delta^{13} \mathrm{C}$ typically occurring between predators and their prey (Cabana and Rasmussen 1996; Vander Zanden et al. 1997).

Combining SIA with traditional diet studies provides a more complete picture of food web structure because it integrates consumer diet history over a long time interval. Additional benefits of SIA include determination of the primary energetic pathway incorporated into the tissue of a consumer from all fish sampled (Chipps and Garvey 2002). Empty stomachs significantly reduce sample size in gut content diet studies (Gerrity et al 2006; Wanner et al. 2007; Grohs et al. 2009) but are not an issue with SIA because nonlethal tissue samples are available from all captured fish (Tieszen et al. 1983). Gut content analysis requires either sacrificing the fish or undertaking stressful and labor-intensive field procedures such as gastric lavage (Wanner et al. 2007) or colonic flushing (Hoover et al. 2007). Researchers can collect nonlethal fin tissue samples for SIA quickly and with a minimal amount of stress to the fish, which is an important consideration for rare fishes (Andvik et al. 2010).

Understanding the trophic relationships and food web linkages of sturgeons is particularly important given the threatened or endangered status of the majority of sturgeon species worldwide (Bemis and Findeis 1994). Given the imperiled status of many sturgeons, and Scaphirhynchus species in particular, obtaining a detailed understanding of their positions in food webs has become a priority of fisheries biologists. The genus Scaphirhynchus contains two species native to the Missouri and Mississippi river systems: the pallid sturgeon S. albus and shovelnose sturgeon S. platorynchus. These two species are morphologically similar, use main channel habitat with fine substrates (Gerrity et al. 2008), and consume benthic macroinvertebrate prey (Gerrity et al. 2006; Hoover et al. 2007; Wanner et al. 2007). However, pallid sturgeon grow larger (max size $\sim 1,500 \mathrm{~mm}$ ) than shovelnose sturgeon (max size $\sim 1,000 \mathrm{~mm}$ ) and are generally piscivorous as adults (Pflieger 1997). The pallid sturgeon is a federally endangered species (U.S. Endangered Species Act [ESA 1973, as amended]; U.S. Fish and Wildlife Service [USFWS] 1990; Dryer and Sandvol 1993; Krentz 2004). Physical and thermal habitat alterations as well as introduced species are threats to species recovery (Bergman et al. 2008). Moreover, the absence of naturally produced juvenile pallid sturgeon in the Missouri River suggests that spawning, recruitment, or both are inadequate for local species survival (Bergman et al. 2008). There is also growing concern over the status of shovelnose sturgeon populations throughout their native range in the face of increasing commercial harvest and habitat alterations (Keenlyne 1997; Quist et al. 2002; Tripp et al. 2009).
Documented harvest of pallid sturgeon by shovelnose sturgeon commercial fishers (Bettoli et al. 2009) led to closure of these fisheries where the species overlap due to their similarity of appearance (USFWS 2010).

Several authors have reported that diet overlap between shovelnose sturgeon and pallid sturgeon is generally low, owing to the increased proportion of fish prey and Ephemeroptera in pallid sturgeon diets (Gerrity et al. 2006; Braaten et al. 2007; Wanner et al. 2007; Grohs et al. 2009). However, this low overlap may be influenced by how studies examined diet composition (e.g., number of prey vs. biomass). Quantifying the importance of prey composition to growth of shovelnose sturgeon and pallid sturgeon has been difficult using gut content diet data because of small sample sizes, no prey items present in sturgeon stomachs, and/or spatiotemporal variation in diet.

Estimated trophic positions and food habits of multiple life stages obtained through a mixture of SIA and stomach content techniques will allow managers to examine the importance of varying prey taxa to Scaphirhynchus and to identify habitats where important prey taxa may be limiting (Bergman et al. 2008; Rapp et al. 2011). Additionally, SIA will allow managers to monitor long-term broad-scale changes in riverine food webs and possible implications for long-lived riverine species. This study examined patterns of $\delta^{15} \mathrm{~N}$ and $\delta^{13} \mathrm{C}$ to infer the effects of body size and sturgeon species on trophic position for pallid sturgeon and shovelnose sturgeon in three reaches of the Missouri River.

\section{Materials and Methods}

\section{Study area}

Remnant, free-flowing reaches of the Missouri River, called Recovery Priority Management Areas (RPMAs; Figure 1), encompass available riverine habitats for stocking hatchery-reared fish as part of short-term recovery efforts for pallid sturgeon (USFWS 2008). Originating in Montana, RPMA 2 incorporates the area downstream of Fort Peck Dam (river kilometer [rkm] 2,850 ) to the headwaters of Lake Sakakawea in North Dakota (rkm 2,496) and the lower $298 \mathrm{rkm}$ of the Yellowstone River. Forming the border of South Dakota and Nebraska, RPMA 3 runs from Fort Randall Dam (rkm $1,416)$ downstream to the headwaters of Lewis and Clark Lake (rkm 1,332). Beginning just downstream of RPMA 3, RPMA 4 extends from Gavins Point Dam (rkm 1,305) downstream to the confluence of the Mississippi River (rkm 0).

\section{Sample collection}

State and federal agencies captured pallid sturgeon ( $n=108)$ and shovelnose sturgeon $(n=95)$ as part of annual standardized sampling (Drobish 2008) in $\mathrm{Ne}$ braska, North Dakota, South Dakota, and Montana (Table 1; Data S1). Sturgeon sampling relied upon trotlines, trammel nets, gill nets, or benthic otter trawls from RPMAs 2, 3, and 4 of the Missouri River (Welker and Drobish 2010). Prior to releasing the fish, researchers obtained a section of pectoral fin from each fish and 


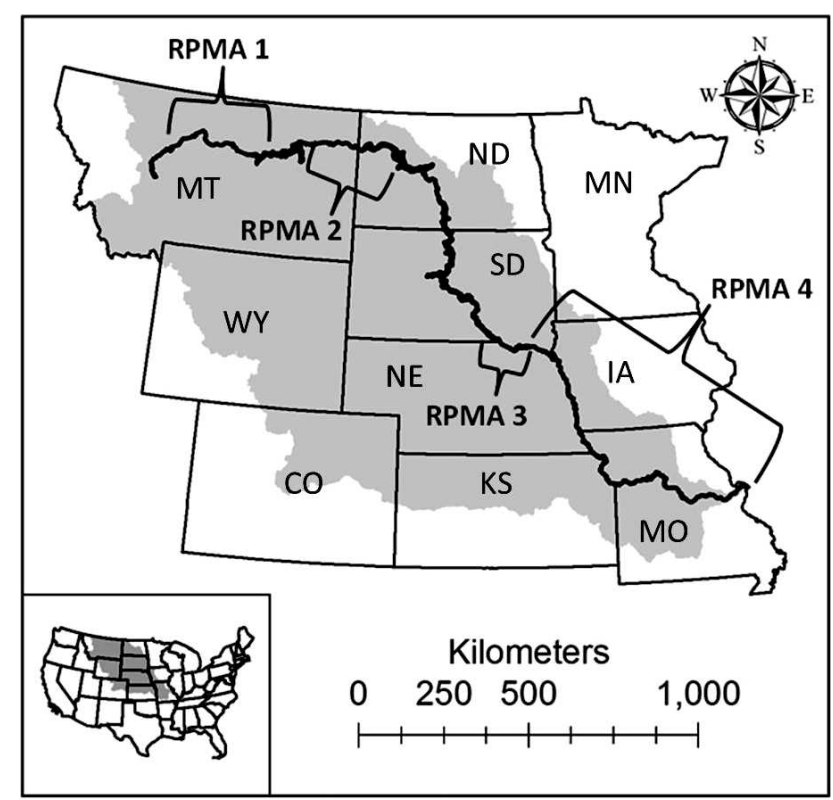

Figure 1. Missouri River and pallid sturgeon Scaphirhynchus albus Recovery Priority Management Areas (RPMA) 1-4. Grayshaded area denotes the Missouri River Basin.

preserved it in 95\% ethanol (RPMAs 2 and 3) or froze it (RPMA 4) until analysis. The agencies did not collect shovelnose sturgeon from RPMA 2 because emphasis was on targeting pallid sturgeon. The majority of the pallid sturgeon in this study were fish of hatchery origin and known age, but genetic analysis revealed that a few of the largest individuals $(>800 \mathrm{~mm}$ ) lacking tags were wild fish (Welker and Drobish 2010; Shuman et al. 2010). All shovelnose sturgeon were wild fish of unknown age.

RPMAs 2-4 contain stocked pallid sturgeon, creating the possibility that fish in the SIA analysis may have acquired signatures in the hatchery. Andvik et al. (2010) found pallid sturgeon reared on a hatchery diet had acquired the isotopic signature of nonhatchery invertebrate prey after 186 days. All pallid sturgeon captured from RPMA 4 had individual tags with passive integrated transponders (PIT), and sampling took place during this study after a minimum of 2 y poststocking (Kirk Steffensen, Nebraska Game and Parks. Lincoln, Nebraska, personal communication). Individual stocking records from PIT tags were also available for most of the pallid sturgeon from RPMAs 2 and 3. Using the results of Andvik et al. (2010) as a guide, we assumed pallid sturgeon sampled in this study before 186 days poststocking may have retained SIA signatures from hatchery feed. Therefore, we removed two pallid sturgeon from RPMA 2 and one pallid sturgeon from RPMA 3 from analysis for this reason. Five pallid sturgeon from RPMA 3 were in the Missouri River for 153-155 d before capture, and we retained those fish for analysis because they had growth rates $(0.4 \mathrm{~g} / \mathrm{d})$ that were $70 \%$ higher than those observed by Andvik et al. (2010). This should result in a faster turnover of hatchery acquired signatures because growth rate has been shown to affect turnover rates of tissues (Trueman et al. 2005).

\section{Sample preparation}

Prior to analysis, we rinsed samples with deionized water, placed them in individual aluminum trays, and dried them at $60^{\circ} \mathrm{C}$ for $72 \mathrm{~h}$. After drying, we homogenized samples into a fine powder using a mortar and pestle and placed them into individually labeled glass scintillation vials. Approximately $0.08 \mathrm{mg}( \pm 0.002)$ of the homogenized tissue went into individual tin capsules. We sent samples to the Cornell Isotope Laboratory (COIL, Cornell University, Ithaca, New York; http://www.cobsil.com/) for carbon $\left(\delta^{13} \mathrm{C}\right)$ and nitrogen $\left(\delta^{15} \mathrm{~N}\right)$ analysis using a Thermo Delta $\mathrm{V}$ Isotope Ratio Mass Spectrometer interfaced to a Carlo Erba NC2500 elemental analyzer.

As a preservation medium, ethanol can affect $\delta^{13} \mathrm{C}$ and $\delta^{15} \mathrm{~N}$ signatures in tissues of fish, primarily due to interactions with lipids within the tissues (Sweeting et al. 2004). As lipid content can vary considerably between species, species-specific correction factors are necessary to reduce sampling error due to preservation effects. We adjusted the pallid sturgeon $\delta^{15} \mathrm{~N}$ values from samples preserved in ethanol (RPMAs 2,3) for preservation effects using a regression developed from captive pallid sturgeon (Andvik et al. 2010). Because the regression model to correct for ethanol preservation effects on $\delta^{13} \mathrm{C}$ signatures in pallid sturgeon had a poor fit $\left(R^{2}=0.16\right.$; Andvik et al. 2010), we did not adjust samples from RPMAs 2 and 3. We also did not adjust ethanol-preserved shovelnose sturgeon samples from RPMA 3 for either element because no correction factor was available for shovelnose sturgeon. We only analyzed shovelnose sturgeon values from ethanol-preserved tissue in RPMA 3 , where pallid sturgeon tissue also was preserved in ethanol.

Lipids are depleted in $\delta^{13} \mathrm{C}$ and have the potential to bias analyses in tissues with high lipid content. There are

Table 1. Sample size, size range (fork length [FL]), and collection period of pallid sturgeon Scaphirhynchus albus and shovelnose sturgeon Scaphirhynchus platorynchus from Recovery Priority Management Areas (RPMAs) 2-4 of the Missouri River. Samples from RPMA 4 were frozen; samples from RPMAs 2 and 3 were preserved in ethanol.

\begin{tabular}{|c|c|c|c|c|c|c|}
\hline \multirow[b]{2}{*}{ Location } & \multicolumn{3}{|c|}{ Shovelnose sturgeon } & \multicolumn{3}{|c|}{ Pallid sturgeon } \\
\hline & $N$ & $\begin{array}{l}\text { Collection } \\
\text { period }\end{array}$ & $\begin{array}{c}\text { Size range } \\
\text { (FL, mm) }\end{array}$ & $N$ & $\begin{array}{c}\text { Collection } \\
\text { period }\end{array}$ & $\begin{array}{c}\text { Size range } \\
\text { (FL, } \mathrm{mm} \text { ) }\end{array}$ \\
\hline RPMA 2 & - & - & - & 18 & Jul-Aug 2008 & $182-681$ \\
\hline RPMA 3 & 72 & Aug 2005-Nov 2008 & $555-763$ & 42 & Aug 2005-Nov 2008 & $301-1187$ \\
\hline RPMA 4 & 23 & Mar 2008 & $341-719$ & 48 & Mar 2008 & $325-1057$ \\
\hline
\end{tabular}


varying methods for dealing with lipids ranging from removal before analysis to mathematical correction models applied postanalysis. However, if lipid content is low it may have minimal effect on $\delta^{13} \mathrm{C}$ signatures and no corrections may be necessary. Many of these mathematical corrections rely on the $\mathrm{C}: \mathrm{N}$ ratio of the sample as a surrogate for lipid content (Kiljunen et al. 2006; Sweeting et al. 2006; Post et al. 2007). Post (2002) found lipid correction models minimally affected results from tissues with a $\mathrm{C}: \mathrm{N}$ ratio of less than 3.5. The mean $\mathrm{C}: \mathrm{N}$ ratio of the fin tissue samples in this study was 3.13 ( $\pm 0.06 \mathrm{SE}$ ), so correcting for lipid removal was not necessary.

\section{ANCOVA and linear regression}

We used ANCOVA to determine if an interaction between $\mathrm{FL}$ and sturgeon species had an effect on $\delta^{15} \mathrm{~N}$ and $\delta^{13} \mathrm{C}$ enrichment in RPMAs 3 and 4 (Table S1, Supplemental Material). The ANCOVA model was as follows: $\mathrm{N}$ or $\mathrm{C}=\operatorname{species}(2$ levels) $+\mathrm{FL}$ (covariate) + species* ${ }^{*} \mathrm{interaction}$. If we found significant interactions within an RPMA, then we applied separate linear regression models to each species. We used linear regression to examine size effects (FL) on $\delta^{15} \mathrm{~N}$ and $\delta^{13} \mathrm{C}$ enrichment in pallid sturgeon in RPMA 2, and separately for pallid sturgeon and shovelnose sturgeon in RPMAs 3 and 4. In situations with curvilinear data, we compared $R^{2}$ values of linear and curvilinear models and used the model with the highest $R^{2}$ value.

\section{Analysis of variance}

We used ANOVA (ANOVA N or C = size [three levels]) to compare trophic position between three groups of sturgeon: small pallid, large pallid, and shovelnose sturgeon. We grouped pallid sturgeon into small $(<500 \mathrm{~mm})$ or large $(>500 \mathrm{~mm})$ size categories based on the approximate size observed in field studies when pallid sturgeon became mostly piscivorous. Fish composed $>50 \%$ of dry weight of pallid sturgeon diets for fish of $>500 \mathrm{~mm} \mathrm{FL} \mathrm{(Grohs} \mathrm{et} \mathrm{al.} \mathrm{2009).} \mathrm{In} \mathrm{contrast,} \mathrm{we}$ analyzed shovelnose sturgeon as a single group regardless of body size since benthic macroinvertebrates were predominant in their diets at all length classes (Held 1969; Modde and Schmulbach 1977; Berry 2002; Braaten et al. 2007).

If we detected differences among sturgeon groups using ANOVA, we used a pairwise $t$ test with Bonferroni's adjustment for multiple comparisons to compare trophic position between groups (Bonferroni 1936). We performed all analyses in SAS (2009) with an $\alpha=0.05$. We only compared mean $\delta^{15} \mathrm{~N}$ and $\delta^{13} \mathrm{C}$ values for large and small pallid sturgeon and shovelnose sturgeon graphically for RPMA 3 because tissue samples were preserved in ethanol.

The evaluation of relative trophic position and energy flow within a system is straightforward using stable isotope values (Post 2002). However, comparisons across systems require baseline corrections to isotope values to account for considerable variation in $\delta^{15} \mathrm{~N}$ and $\delta^{13} \mathrm{C}$ at the base of the food web. Without information on isotope values of lower trophic levels from each river segment, we could not evaluate differences in trophic position for pallid sturgeon and shovelnose sturgeon among RPMAs. As a result, we limited our analysis to general patterns of trophic structure as related to body size and between pallid sturgeon and shovelnose sturgeon within each RPMA.

\section{Results}

\section{ANCOVA and linear regression}

Enrichment of $\delta^{15} \mathrm{~N}$ for pallid sturgeon and shovelnose sturgeon in RPMA 4 increased with increasing body size (Figure 2). FL significantly influenced differences in $\delta^{15} \mathrm{~N}$ signatures of pallid sturgeon and shovelnose sturgeon from RPMA 4 (ANCOVA: $F_{1,70}=28.17, P<0.01$ ) but not by species (ANCOVA: $F_{1,70}=0.84, P=0.36$ ). Pallid sturgeon $\delta^{15} \mathrm{~N}$ values (range: $12.8-16.7 \%$ ) increased with FL (range: $325-1,057 \mathrm{~mm}$ ), showing that small fish transitioned from more depleted $\delta^{15} \mathrm{~N}(13-14 \%$ ) to a more enriched signature (15-17\%0) as they grew. Shovelnose sturgeon $\delta^{15} \mathrm{~N}$ values $\left(\delta^{15} \mathrm{~N}\right.$ range: $14.6-$ $17.2 \%$ ) were also positively correlated with FL (range: 341-719 $\mathrm{mm}$ ) but spanned a narrower range than those of pallid sturgeon.

Comparison of $\delta^{13} \mathrm{C}$ signatures for pallid sturgeon and shovelnose sturgeon in RPMA 4 revealed a significant interaction between FL and species (ANCOVA: $F_{1,70}=$ 10.66, $P<0.01)$. Therefore, we fit separate regressions for each species: pallid sturgeon, $R^{2}=0.34, N=48, P<$ 0.01 ; shovelnose sturgeon $R^{2}=0.21, N=23, P<0.05$. Pallid sturgeon $\delta^{13} \mathrm{C}$ values $\left(\delta^{13} \mathrm{C}\right.$ range: -23.4 to -18.0 ) in RPMA 4 increased with $\mathrm{FL}$, whereas shovelnose sturgeon $\delta^{13} \mathrm{C}$ values $\left(\delta^{13} \mathrm{C}\right.$ range $=-23.7$ to -20.1$)$ decreased with FL.

Analysis of $\delta^{15} \mathrm{~N}$ signatures of pallid sturgeon and shovelnose sturgeon in RPMA 3 revealed a significant interaction between FL and species (ANCOVA: $F_{1,110}=$ 15.09, $P<0.01)$; whereas, the interaction for $\delta^{13} \mathrm{C}$ signatures was insignificant. We fit separate regressions to $\delta^{15} \mathrm{~N}$ signature by $\mathrm{FL}$ for each species: pallid sturgeon $R^{2}=0.34, N=42, P<0.01$; shovelnose sturgeon $R^{2}=$ $0.01, N=72, P=0.40$ (Figure 3). Pallid sturgeon $\delta^{15} \mathrm{~N}$ signatures in RPMA 3 increased with FL, while shovelnose sturgeon $\delta^{15} \mathrm{~N}$ signatures showed no relationship with FL. Comparisons of $\delta^{13} \mathrm{C}$ signatures of pallid sturgeon and shovelnose sturgeon in RPMA 3 showed significant main effects of FL (ANCOVA: $F_{1,110}=9.8, P<0.01$ ) and species (ANCOVA: $F_{1,110}=5.6, P=0.02$ ).

The relation of pallid sturgeon body size to $\delta^{15} \mathrm{~N}$ and $\delta^{13} \mathrm{C}$ in RPMA 2 was similar to RPMA 3, regression analysis showed pallid sturgeon $\delta^{15} \mathrm{~N}$ signature in RPMA 2 increased with FL: $R^{2}=0.48, N=18, P<0.01$ (Figure 4). There was no significant relationship between $\delta^{13} \mathrm{C}$ signatures and FL of pallid sturgeon in RPMA 2.

\section{Analysis of variance}

There were significant differences in $\delta^{13} \mathrm{C}\left(F_{2,70}=\right.$ 26.51, $P<0.001)$ and $\delta^{15} \mathrm{~N}\left(F_{2,70}=29.94, P<0.001\right)$ among sturgeon groups in RPMA 4 (Figure 5, Table 2). Small pallid sturgeon and shovelnose sturgeon had similar $\delta^{13} \mathrm{C}$ signatures. Large pallid sturgeon had more 

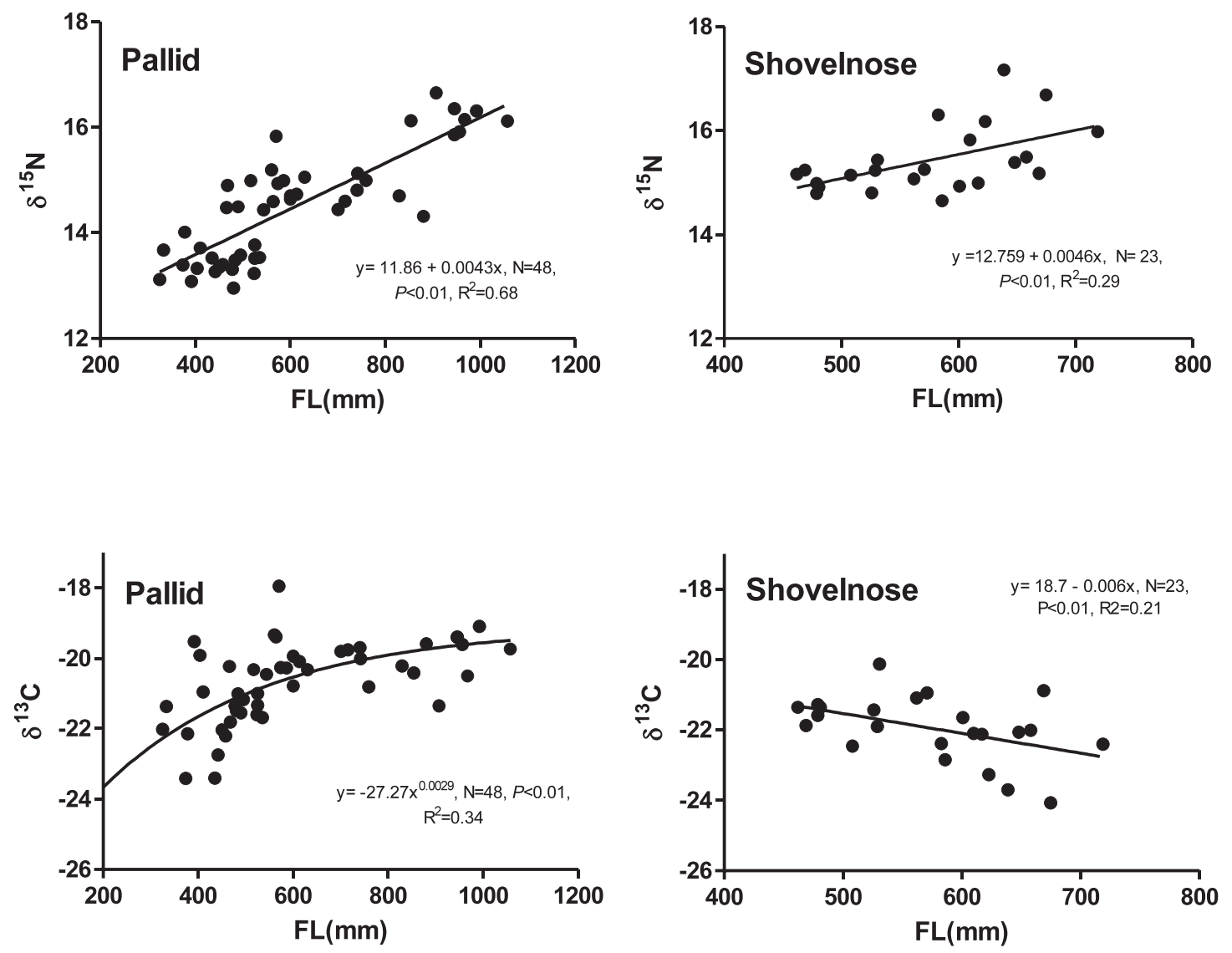

Figure 2. Regressions of $\delta^{15} \mathrm{~N}(\%)$ signature and fork length ( $\mathrm{mm}$ ) for pallid sturgeon Scaphirhynchus albus (Pallid) and shovelnose sturgeon Scaphirhynchus platorynchus (Shovelnose) and $\delta^{13} \mathrm{C}(\%)$ signature and fork length (mm) for pallid sturgeon and shovelnose sturgeon from Recovery Priority Management Area 4 of the Missouri River during 2008.

enriched $\delta^{13} \mathrm{C}$ signatures than small pallid sturgeon and shovelnose sturgeon. Small pallid sturgeon and all shovelnose sturgeon had similar $\delta^{13} \mathrm{C}$ signatures, but small pallid sturgeon had less enriched $\delta^{15} \mathrm{~N}$ signatures than all shovelnose sturgeon. Large pallid sturgeon $\delta^{13} \mathrm{C}$ signatures were significantly more enriched than all shovelnose sturgeon and small pallid sturgeon. Large pallid sturgeon $\delta^{15} \mathrm{~N}$ signatures were similar to all shovelnose sturgeon but significantly more enriched than small pallid sturgeon. Graphically, the relative positions of shovelnose sturgeon and the two pallid sturgeon size classes in RPMA 3 were similar to RPMA 4.

\section{Discussion}

Patterns of pallid sturgeon and shovelnose sturgeon isotope composition corroborate previous studies based on field-derived diet information that found use of invertebrate prey by small, young pallid sturgeon and an ontogenetic diet shift to increased piscivory in large juveniles and adults (Carlson et al. 1985; Hoover et al. 2007; Wanner et al. 2007; Grohs et al. 2009). The relationship between $\delta^{15} \mathrm{~N}$ signatures and fish size in the current study suggests that large pallid sturgeon fed at a higher trophic level than small pallid sturgeon. Moreover, $\delta^{15} \mathrm{~N}$ signatures of pallid sturgeon $>800 \mathrm{~mm}$ were separated by a full trophic level (i.e., $>3.4 \%$ ) from smaller pallid sturgeon $(<400 \mathrm{~mm})$. However, intermediate $\delta^{15} \mathrm{~N}$ signatures for 500 to $800 \mathrm{~mm}$ pallid sturgeon suggested that this transition in diet was gradual. This transition was most evident in RPMAs 3 and 4, where our samples included the largest size range of pallid sturgeon. Wanner et al. (2007) and Grohs et al. (2009) found invertebrate as well as fish prey in the stomach contents of pallid sturgeon of $>500-\mathrm{mm} \mathrm{FL}$, also indicating a gradual transition to piscivory.

Pallid sturgeon $\delta^{13} \mathrm{C}$ signatures in RPMA 4 varied with increasing $\mathrm{FL}$, indicating the energy source changed as sturgeon grew, possibly resulting from a shift in diet. We observed a similar pattern in pallid sturgeon $\delta^{13} \mathrm{C}$ signatures in RPMA 3; however, pallid sturgeon $\delta^{13} \mathrm{C}$ signatures in RPMA 2 showed no significant relationship with FL. This may have been due to the smaller sample size from RPMA 2 and (or) the smaller size range of pallid sturgeon from this reach compared with RPMAs 3 and 4 . While our lack of basal isotope signatures for each RPMA prevents direct comparisons across river segments, pallid sturgeon in all RPMAs displayed an enrichment of $\delta^{15} \mathrm{~N}$ with increasing FL. Additionally, pallid sturgeon in RPMAs 3 and 4 displayed enrichment in $\delta^{13} \mathrm{C}$ with increasing FL. These observed patterns of $\delta^{15} \mathrm{~N}$ and $\delta^{13} \mathrm{C}$ enrichment in each RPMA are consistent with the expectation of an ontogenetic diet shift to piscivory. 

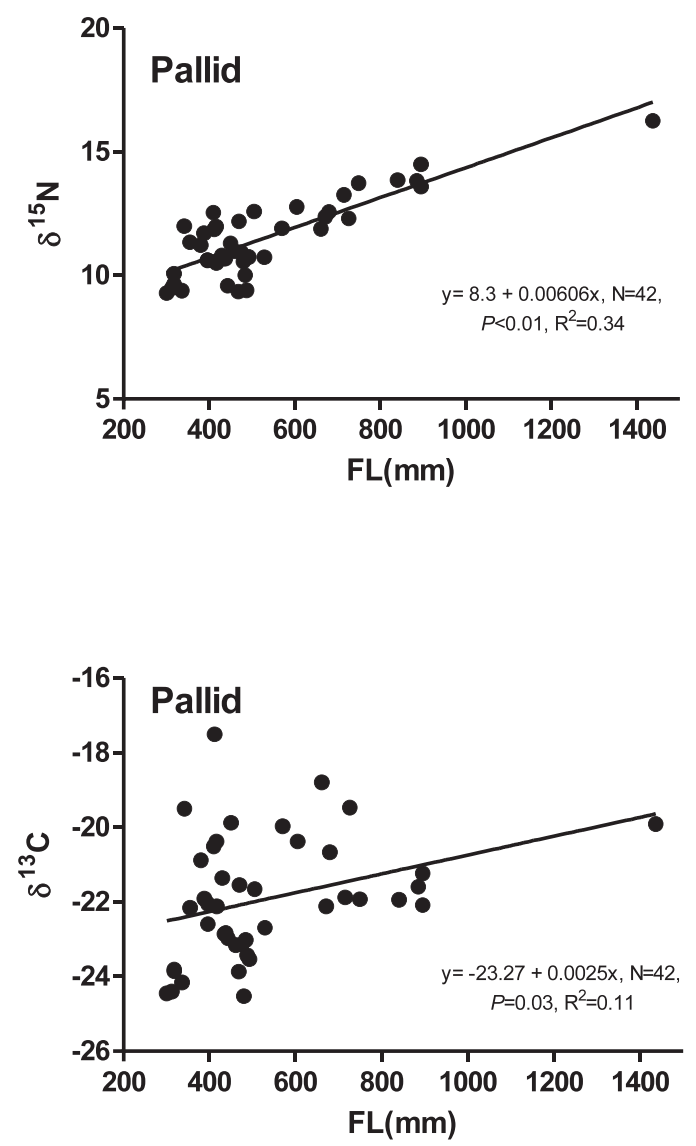
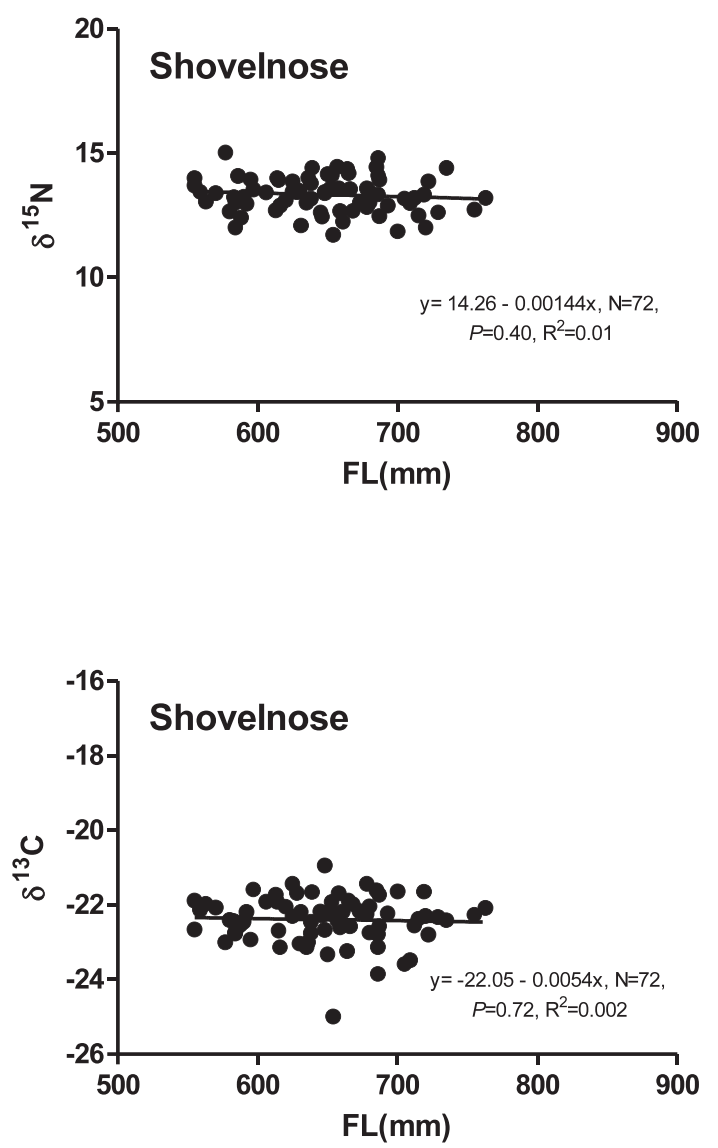

Figure 3. Regressions of $\delta^{15} \mathrm{~N}(\%)$ signature and fork length ( $\mathrm{mm}$ ) for pallid sturgeon Scaphirhynchus albus (Pallid) and shovelnose sturgeon Scaphirhynchus platorynchus (Shovelnose) and $\delta^{13} \mathrm{C}(\%)$ signature and fork length (mm) for pallid sturgeon and shovelnose sturgeon from Recovery Priority Management Area 3 of the Missouri River during 2005-2008. Samples were preserved in ethanol, correction factors were applied to pallid sturgeon $\delta^{15} \mathrm{~N}$ signatures.

For shovelnose sturgeon in RPMA 4 the relationship between $\delta^{15} \mathrm{~N}$ and $\mathrm{FL}$ spanned a narrower range than that in pallid sturgeon and suggested most foraging occurred at a single trophic level for the majority of sampled fish. The similar enrichment of $\delta^{15} \mathrm{~N}$ signatures between pallid sturgeon and shovelnose sturgeon was unexpected because field studies of shovelnose sturgeon diets in the Missouri and Platte rivers found benthic macroinvertebrates were the dominant prey in all length classes of fish, with piscivory being rare (Held 1969; Modde and Schmulbach 1977; Berry 2002; Braaten et al. 2007; Wanner et al. 2007; Rapp et al. 2011). There was no significant relationship between $\mathrm{FL}$ and $\delta^{15} \mathrm{~N}$ for shovelnose sturgeon in RPMA 3, which was likely due to the truncated size distribution of our samples. In RPMA 3, no capture of shovelnose sturgeon $<475 \mathrm{~mm}$ occurred from 2003 to 2010 (Shuman et al. 2010), indicating an aging population with minimal recruitment.

Sampling of pallid sturgeon and shovelnose sturgeon occurred in RPMA 3 from 2005 to 2008, while sampling in the other RPMAs only occurred during 2008. If Missouri River food webs changed during this time, there is the possibility that the broader temporal scale for RPMA 3 may have had some effect on $\delta^{15} \mathrm{~N}$ and $\delta^{13} \mathrm{C}$ enrichment, although the similar patterns in each RPMA suggest that any effects of sampling period were minimal. Additionally, since we treated each RPMA as a separate system in our analysis and avoided direct comparisons between RPMAs, the temporal synchronization of sampling in each RPMA is not critical to our interpretations. We believe the similarity of patterns in RPMA 3 from 2005 to 2008 to those from RPMAs 2 and 4 in 2008 may indicate food web stability in the highly regulated Missouri River (Pegg et al. 2003).

Similarity in $\delta^{15} \mathrm{~N}$ signatures between pallid sturgeon and shovelnose sturgeon was unexpected given the piscivorous nature of adult pallid sturgeon (Carlson et al. 1985). One explanation for this may involve the observed differences in invertebrate diet composition between shovelnose and pallid sturgeon. Grohs et al. (2009), for example, showed that Ephemeroptera represented a significant proportion of pallid sturgeon diets $(\sim 25 \%$ by weight), whereas net-spinning caddisflies (Trichoptera: Hydropsychidae) only represented about $0.3 \%$. In contrast, a detailed study of shovelnose sturgeon diets in the Missouri River showed that Hydropsychidae represented over $50 \%$ of the diet by wet weight (Modde and Schmulbach 1977). Analysis of the feeding ecology of Hydropsychidae found animal remains constituted a significantly higher proportion of diet in spring and summer, especially for later larval developmental stages (Fuller and Mackay 1980). In a previous study, omnivorous or predatory aquatic invertebrates had elevated 

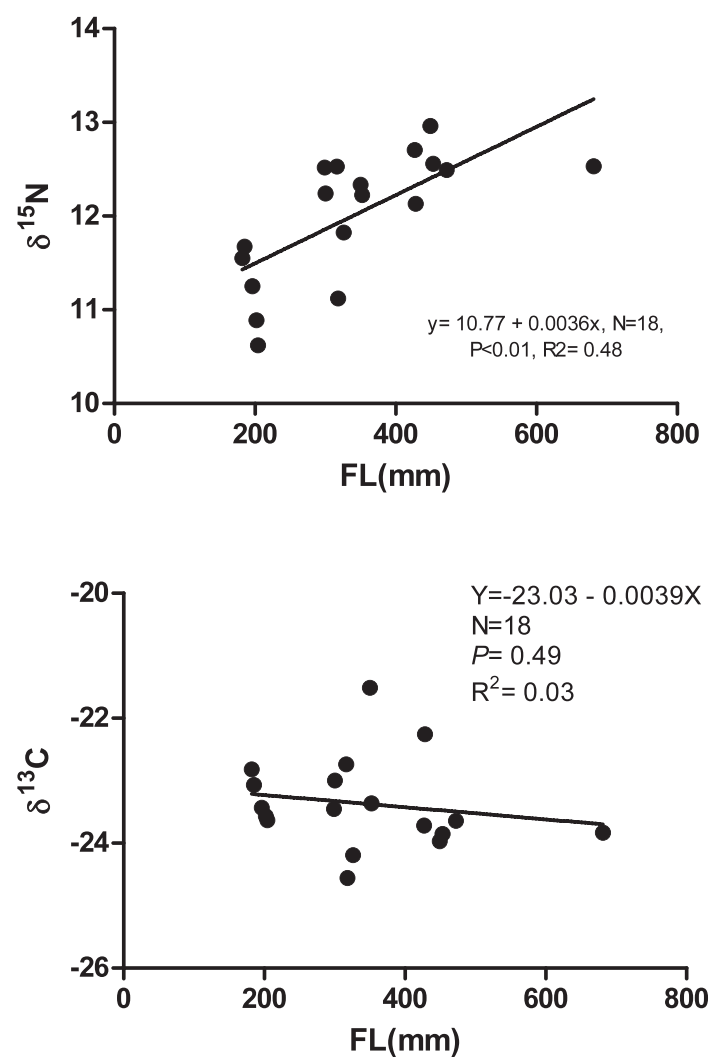

Figure 4. Regressions of $\delta^{15} \mathrm{~N}(\% 0)$ signature by fork length $(\mathrm{mm})$ and $\delta^{13} \mathrm{C}(\%)$ signature by fork length ( $\mathrm{mm}$; not significant) for pallid sturgeon Scaphirhynchus albus from Recovery Priority Management Area (RPMA) 2 during 2008. Samples were preserved in ethanol, correction factors were applied to $\delta^{15} \mathrm{~N}$ signatures.

trophic levels and $\delta^{15} \mathrm{~N}$ signatures in relation to herbivorous invertebrates in the same locations; for example, carnivorous opossum shrimp Mysis relicta had a $\delta{ }^{15} \mathrm{~N}$ signature more than 3\%o greater than herbivorous opossum shrimp (Branstrator et al. 2000). Thus, a higher proportion of invertebrates (i.e., Hydropsychidae) with potentially enriched $\delta^{15} \mathrm{~N}$ values may have contributed to enriched $\delta^{15} \mathrm{~N}$ values we observed for shovelnose sturgeon. Similarly, fish eggs can be part of the diets of shovelnose sturgeon in RPMA 3 (Dane Shuman, U.S. Fish and Wildlife Service. Pierre, South Dakota, personal communication) and could potentially increase $\delta^{15} \mathrm{~N}$ signatures if consumed in significant amounts. However, the overall significance of fish eggs to the diet of shovelnose sturgeon is unknown.

Changes in invertebrate prey composition for shovelnose sturgeon may also explain the observed decrease in $\delta^{13} \mathrm{C}$ signatures with increasing FL in RPMA 4; although, this decrease was less pronounced than the increase in pallid sturgeon $\delta^{13} \mathrm{C}$ signatures. Previous researchers have documented variation in $\delta^{13} \mathrm{C}$ signatures within a site, even among closely related species. Trichopterans in a New Zealand stream had mean $\delta^{13} \mathrm{C}$ values vary by over $2 \%$ between species (Rounick et al. 1982). The decrease in $\delta^{13} \mathrm{C}$ signatures we observed potentially could have been caused by large shovelnose sturgeon

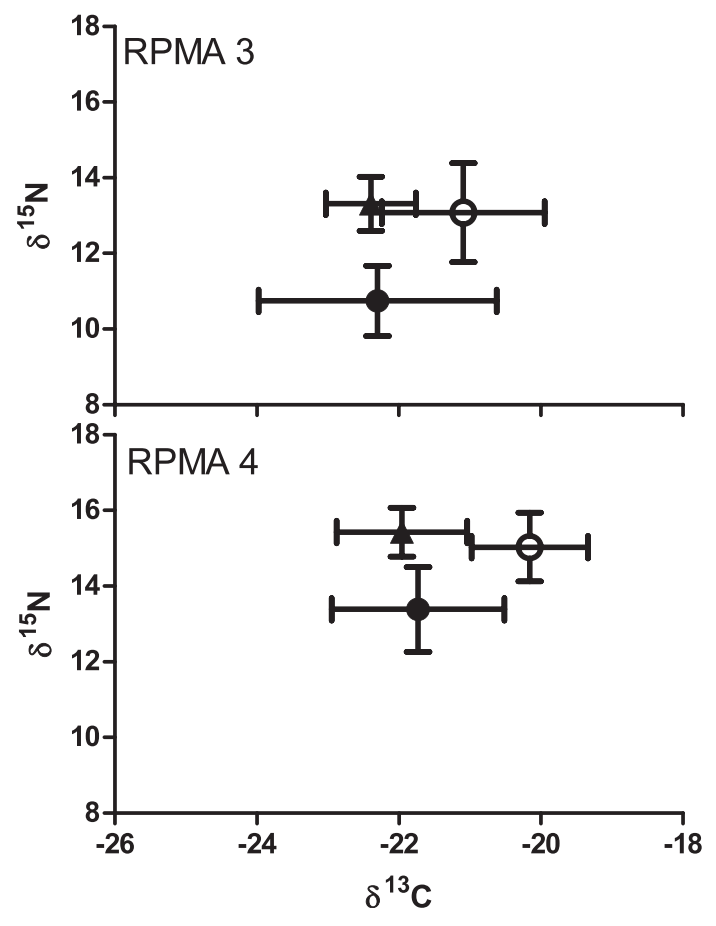

Figure 5. Biplot of mean $\delta^{13} \mathrm{C}$ and $\delta^{15} \mathrm{~N}$ isotope signatures $(\%, \pm 1 \mathrm{SD})$ for small $(<500 \mathrm{~mm} \mathrm{FL})$ and large $(>500 \mathrm{~mm} \mathrm{FL})$ pallid sturgeon Scaphirhynchus albus and shovelnose sturgeon Scaphirhynchus platorynchus collected from Recovery Priority Management Area (RPMA) 4 and RPMA 3 of the Missouri River. Closed circles represent pallid sturgeon of $<500 \mathrm{~mm}$. Open circles represent pallid sturgeon of $>500 \mathrm{~mm}$. Triangles represent shovelnose sturgeon.

foraging on different invertebrate prey as they grew and also potentially influenced pallid sturgeon stable isotope signatures. Detailed taxonomic resolution (i.e., genus level) is generally lacking for diet studies of both species (Carlson et al. 1985; Berry 2002; Gerrity et al. 2006; Hoover et al. 2007; Wanner et al. 2007; Grohs et al. 2009).

Table 2. Mean differences (MD) and pairwise $t$ tests comparing mean $\delta^{15} \mathrm{~N}$ and $\delta^{13} \mathrm{C}$ between sturgeon groups; $\alpha=0.05$ for all comparisons.

\begin{tabular}{lcc}
\hline Comparison & ${ }^{15} \mathbf{N}$ & ${ }^{13} \mathbf{C}$ \\
\hline Small pallid vs. large pallid & & \\
$t_{69, \alpha=0.016}$ & 6.40 & 5.31 \\
$P$ & $<0.01^{\mathrm{a}}$ & $<0.01^{\mathrm{a}}$ \\
$\mathrm{MD}$ & $\delta 1.4 \% 0$ & $\delta 1.5 \% 0$ \\
Small pallid vs. shovelnose ${ }^{\mathrm{a}}$ & & \\
$t_{69, \alpha=0.016}$ & 8.13 & -1.43 \\
$P$ & $<0.01^{\mathrm{a}}$ & $>0.05$ \\
MD & $\delta 1.9 \% 0$ & $\delta 0.4 \%$ \\
\hline Large pallid vs. shovelnose & & \\
$t_{69, \alpha=0.016}$ & -2.14 & 7.40 \\
$P$ & $>0.05$ & $<0.01^{\mathrm{a}}$ \\
$M D$ & $\delta 0.5 \% 0$ & $\delta 1.9 \% 0$ \\
\hline
\end{tabular}

a Significant. 
However, Rapp et al. (2011) found four genera of Chironomidae comprised over $80 \%$ of ingested diet items by shovelnose sturgeon in the Platte River in Nebraska.

Alternatively, the variability in $\delta^{15} \mathrm{~N}$ signatures of shovelnose sturgeon may be partially due to variation in age because $\delta^{15} \mathrm{~N}$ signatures can become enriched in older fish, independent of diet. Overman and Parrish (2001) found $81 \%$ of variation in walleye Sander vitreus $\delta^{15} \mathrm{~N}$ signatures (range: $15.3-19.2 \%$ ) was due to age (range: $2-27 \mathrm{y}$ ). ${ }^{15} \mathrm{~N}$ accumulation over the lifespan of the fish may explain this enrichment. The majority of pallid sturgeon in this study were juveniles and early adults of known age from PIT tagging records. Additionally, the size of the few unknown pallid sturgeon suggests a similar age range ( $<850-\mathrm{mm} \mathrm{FL}$ and age $<12$ y; Keenlyne and Jenkins 1993), whereas shovelnose sturgeon were not PIT tagged and of unknown age. Everet et al. (2003) found ages ranged from 12 to 30 y for 500 to $600 \mathrm{~mm} \mathrm{FL}$ shovelnose sturgeon in the Missouri River downstream of Garrison Dam in North Dakota. Thus, the enrichment in shovelnose sturgeon $\delta^{15} \mathrm{~N}$ signatures relative to those of pallid sturgeon may have been partially due to differences in ages of fish in our samples. Regardless, the unexpectedly enriched $\delta^{15} \mathrm{~N}$ signatures of shovelnose sturgeon warrant further investigation because any number of factors (including shifts in diet) may have caused enrichment similar to that in pallid sturgeon.

The divergence of $\delta^{13} \mathrm{C}$ signatures of large $(>500 \mathrm{~mm})$ pallid sturgeon from those of small pallid sturgeon and all shovelnose sturgeon supported previous findings of an ontogenetic shift to piscivory among pallid sturgeon (Grohs et al. 2009). Large pallid sturgeon used different energy resources than shovelnose sturgeon or small pallid sturgeon (Figure 5). Small differences in $\delta^{13} \mathrm{C}$ signature can represent important changes in food web structuring. Within RPMA 4, the differences in $\delta^{13} \mathrm{C}$ signature between large pallid sturgeon and shovelnose sturgeon (mean difference $=1.9 \%$ ) and between large and small pallid sturgeon (mean difference $=1.5 \%$ ) are comparable to the differences in $\delta^{13} \mathrm{C}$ signatures from the literature after significant changes in food web dynamics. For example, lake trout Salvelinus namaycush $\delta^{13} \mathrm{C}$ had a mean difference of $1.8 \%$ after a shift from a littoral fish diet to pelagic zooplankton (Vander Zanden et al. 1999). Cucherousset et al. (2007) observed a mean difference of $1.6 \%$ for brown trout Salmo trutta after the introduction of nonnative brook trout Salvelinus fontinalis. Similar shifts in $\delta^{13} \mathrm{C}$ signatures occurred for age-0 largemouth bass Micropterus salmoides (mean difference $=0.8 \%$; Yasuno et al. 2012) during a shift to piscivory and for walleye after an introduction of smallmouth bass (mean difference $=1.7-2.7 \%$; Galster et al. 2012).

The $\delta^{13} \mathrm{C}$ signatures of small pallid sturgeon and shovelnose sturgeon show that they used similar energy resources in RPMAs 3 and 4. In contrast, previous studies found low diet overlap between juvenile pallid sturgeon and shovelnose sturgeon (Gerrity et al. 2006; Wanner et al. 2007). However, the majority of pallid sturgeon in these studies were larger than $500 \mathrm{~mm}$, and the low degree of overlap was primarily driven by fish prey in pallid sturgeon diets. Gerrity et al. (2006) sampled pallid sturgeon (mean FL $=538 \mathrm{~mm}$ ) from the upper Missouri River in Montana (upstream of RPMA 2), where they found diets dominated by fish, primarily native cyprinids of the genus Machrybopsis. Machrybopsis spp. are less abundant in the middle and lower Missouri River than in the upper Missouri River (Dieterman and Galat 2004). Wanner et al. (2007) found johnny darters Etheostoma nigrum ( $n=3$ ) and small channel catfish Ictalurus punctatus ( $n=4$ ) composed the majority of fish in the diet of pallid sturgeon ( $n=28$, mean $\mathrm{FL}=585 \mathrm{~mm}$ ) from the middle Missouri River (RPMA 3), suggesting pallid sturgeon may be able to forage on a variety of potential prey, given variations in local abundances.

Preservation techniques affect stable isotope signatures (Kelly et al. 2006; Sweeting et al. 2004); however, samples preserved in ethanol provide reasonable estimates of isotopic signatures and the development of species-specific correction factors allow researchers to minimize bias from preservation technique (Edwards et al. 2002; Schmidt et al. 2009). We applied existing correction factors for pallid sturgeon $\delta^{15} \mathrm{~N}$ (Andvik et al. 2010) to our ethanol-preserved samples in RPMAs 2 and 3. Despite different preservation techniques, the relative patterns of increased $\delta^{15} \mathrm{~N}$ enrichment with pallid sturgeon size were consistent in the three Missouri River RPMAs. The relative relation of shovelnose sturgeon $\delta^{13} \mathrm{C}$ and $\delta^{15} \mathrm{~N}$ signatures to small and large pallid sturgeon was also similar in RPMAs 3 and 4.

In this study we compare $\delta^{15} \mathrm{~N}$ and $\delta^{13} \mathrm{C}$ enrichment patterns of pallid sturgeon and shovelnose sturgeon within systems (i.e., within rather than between RPMAs). Post (2002) summarized why stable isotope comparisons within a system are relatively straightforward, although baseline isotopic values are necessary to address ecological questions between systems. In such situations, baseline isotopic signatures act as a scalar and allow comparisons between systems by weighting isotopic signatures of the organisms of interest against a baseline organism of known trophic position. In the case of comparisons within a system, however, the baseline scalar will have no effect on observed patterns or relative trophic position of the organisms of interest because it will affect all isotopic signatures in exactly the same way. Thus, our within system comparisons are valid in the absence of baseline isotopic values because the application of baseline scalars would not differentially affect relative $\delta^{15} \mathrm{~N}$ enrichment of pallid sturgeon and shovelnose sturgeon.

Our findings show that stable isotope analysis is an effective tool for investigating relative trophic position of sturgeons in large rivers. Although there have been several diet studies of pallid sturgeon and shovelnose sturgeon (Berry 2002; Gerrity et al. 2006; Braaten et al. 2007; Hoover et al. 2007; Wanner et al. 2007; Grohs et al. 2009), the limitations of stomach content studies (i.e., absence of prey items in predator stomachs, small sample sizes, stressful handling procedures) make SIA an attractive technique when working with rare or endangered species such as sturgeons. The incorporation of stable isotope techniques will aid researchers in 
rapidly obtaining a more accurate picture of sturgeon trophic interactions by eliminating many of the limitations inherent in stomach content analysis. Additionally, SIA will provide a long-term picture of diet composition rather than the brief snapshot obtained via stomach contents. This long-term approach not only complements existing stomach content data, but may be of greater value for long-lived fishes such as sturgeons. Our study supports the conclusions of field-based studies of diet composition (Modde and Schmulbach 1977; Hoover et al. 2007; Wanner et al. 2007) that shovelnose sturgeon do not occupy the same niche as pallid sturgeon as a result of their distinct foraging habits. The establishment of a baseline isotope composition of sturgeon allows fisheries researchers to monitor the impacts of future disturbances (i.e., changes in the aquatic community, hydrologic variation, introduction of exotic species) within the ecosystem and better predict their effects on sturgeon populations.

\section{Supplemental Materials}

Please note: The Journal of Fish and Wildlife Management is not responsible for the content or functionality of any supplemental material. Queries should be directed to the corresponding author for the article.

Data S1. Sturgeon were collected from RPMAs 2-4 of the Missouri River between 2005 and 2008. Excel spreadsheet containing all data used in the analyses presented in this manuscript. Sturgeon species (pallid sturgeon Scaphirhynchus albus and shovelnose sturgeon Scaphirhynchus platorynchus), fork length (mm), Recovery Priority Management Areas (RPMAs), and ${ }^{15} \mathrm{~N}$ and ${ }^{13} \mathrm{C}$ signatures are provided.

Found at DOI: http://dx.doi.org/10.3996/022012-JFWM013.S1 (41 KB XLS).

Table S1. Analyses performed for pallid sturgeon Scaphirhynchus albus and shovelnose sturgeon Scaphirhynchus platorynchus collected from Recovery Priority Management Areas (RPMA) 2-4 of the Missouri River between August 2005 and March 2008.

Found at DOI: http://dx.doi.org/10.3996/022012-JFWM013.S2 (28 KB DOCX).

Reference S1. Bergman HL et al. Research needs and management strategies for pallid sturgeon recovery. Report to the U.S. Army Corps of Engineers. Proceedings of a workshop held July 31-August 2, 2007, St. Louis, Missouri.

Found at DOI: http://dx.doi.org/10.3996/022012-JFWM$013 . S 3$ (2.9 MB PDF).

Reference S2. Berry CR Jr. 2002. Diet of shovelnose sturgeon downstream from Gavins Point Dam. Final report.

Found at DOI: http://dx.doi.org/10.3996/022012-JFWM$013 . S 4$ (916 KB PDF).

Reference S3. Drobish MR. 2008. Pallid sturgeon population assessment program.

Found at DOI: http://dx.doi.org/10.3996/022012-JFWM$013 . S 5$ (324 KB PDF).
Reference S4. Dryer MP, Sandvol AJ. 1993. Recovery plan for the pallid sturgeon.

Found at DOI: http://dx.doi.org/10.3996/022012-JFWM013.S6 (1.0 MB PDF).

Reference S5. Welker TL, Drobish MR (eds). 2010. Missouri River Standard Operating Procedures for Fish Sampling and Data Collection, Volume 1.5.

Found at DOI: http://dx.doi.org/10.3996/022012-JFWM013.S7 (2.6 MB PDF).

Reference S6. U.S. Fish and Wildlife Service. 2008: Pallid sturgeon (Scaphirhynchus albus) range-wide stocking and augmentation plan.

Found at DOI: http://dx.doi.org/10.3996/022012-JFWM$013 . S 8$ (457 KB PDF).

Reference S7. Shuman DA, Klumb RA, Wanner GA, Grohs KL. 2010. 2009 Annual report pallid sturgeon population assessment and associated fish community monitoring for the Missouri River: Segments 5 and 6.

Found at DOI: http://dx.doi.org/10.3996/022012-JFWM013.59 (858 KB PDF).

\section{Acknowledgments}

We thank the following for assistance in the field: Ryan Wilson, Everett Nelson, and Zac Sandness (U.S. Fish and Wildlife Service, Missouri River Fish and Wildlife Conservation Office, Bismarck, North Dakota), Dane Shuman, Greg Wanner, and Steve Heutmaker (U.S. Fish and Wildlife Service, Great Plains Fish and Wildlife Conservation Office, Pierre, South Dakota), and Kirk Steffensen and Marty Hamel (Nebraska Game and Parks Commission, Lincoln, Nebraska). We also thank the Journal Subject Editor and three anonymous reviewers for comments on a previous version of this manuscript. All animals used in this study were handled according to animal use and care guidelines established by South Dakota State University (Animal Welfare Assurance no. A3958-01). Funding for this project was provided by the Missouri River Recovery Program, Omaha and Kansas City Districts of the U.S. Army Corp of Engineers, Northwestern Division. Andrew Wuestewald helped with sample preparation in the laboratory.

Any use of trade, product, or firm names is for descriptive purposes only and does not imply endorsement by the U.S. Government.

\section{References}

Andvik RT, VanDeHey JA, Fincel MJ, French WE, Bertrand KN, Chipps SR, Klumb RA, Graeb BDS. 2010. Application of non-lethal stable isotope analysis to assess feeding patterns of juvenile pallid sturgeon Scaphirhynchus albus: a comparison of tissue types and sample preservation methods. Journal of Applied Ichthyology 26:831-835.

Bemis WE, Findeis EK. 1994. The sturgeons' plight. Nature 370:602.

Bergman HL, Boelter AM, Parady K, Fleming C, Keevin T, Latka DC, Korschgen C, Galat DL, Hill T, Jordan G, Krentz S, Nelson-Stastny W, Olson M, Mestl GE, Rouse 
K, Berkley J. 2008. Research needs and management strategies for pallid sturgeon recovery. Proceedings of a workshop held July 31-August 2, 2007, St. Louis, Missouri. Final report to the U.S. Army Corps of Engineers. William D. Ruckelshaus Institute of Environment and Natural Resources, University of Wyoming, Laramie (see Supplemental Material, Reference S1, http://dx.doi.org/10.1996/022012-JFWM-013.S3).

Berry CR Jr. 2002. Diet of shovelnose sturgeon downstream from Gavins Point Dam. Final report. U.S. Geological Survey Cooperative Fish and Wildlife Research Units, South Dakota State University, Brookings (see Supplemental Material, Reference S2, http:// dx.doi.org/10.1996/022012-JFWM-013.S4); also available: http://digitalcommons.unl.edu/cgi/viewcontent. cgi?article $=1058 \&$ context $=$ usarmyceomaha $($ September 2012).

Bettoli PW, Castro-Yerty M, Scholten GD, Heist EJ. 2009. Bycatch of the endangered pallid sturgeon (Scaphirhynchus albus) in a commercial fishery for shovelnose sturgeon (S. platorynchus). Journal of Applied Ichthyology 25:1-4.

Bonferroni CE. 1936. Teoria statistica delle classi e calcolo delle probabilità. Pubblicazioni del $\mathrm{R}$ Istituto Superiore di Scienze Economiche e Commerciali di Firenze 8:362.

Braaten PJ, Fuller DB, McClenning ND. 2007. Diet composition of larval and young of year shovelnose sturgeon in the Upper Missouri River. Journal of Applied Ichthyology 23:516-520.

Branstrator DK, Cabana G, Mazumder A, Rasmussen JB. 2000. Measuring life-history omnivory in the opossum shrimp Mysis relicta with stable nitrogen isotopes. Limnology and Oceanography 45:463-467.

Cabana G, Rasmussen JR. 1996. Comparison of aquatic food chains using nitrogen isotopes. Proceedings of the National Academy of Science of the United States of America 93:10844-10847.

Carlson DM, Pflieger WL, Trial L, Haverland P. 1985. Distributions, biology and hybridization of Scaphirhynchus albus and Scaphirhynchus platorynchus in the Missouri and Mississippi rivers. Environmental Biology of Fishes 14:51-59.

Chipps SR, Garvey J. 2002. Assessment of food habits and feeding patterns. Pages 473-514 in Guy CS, Brown ML, editors. Analysis and interpretation of freshwater fisheries data. Bethesda, Maryland: American Fisheries Society.

Cucherousset J, Aymes JC, Santoul F, Céréghino R. 2007. Stable isotope evidence of trophic interactions between introduced brook trout Salvelinus fontinalis and native brown trout Salmo trutta in a mountain stream of south-west France. Journal of Fish Biology 71:210-223.

Dieterman DJ, Galat DL. 2004. Large-scale factors associated with sicklefin chub distribution in the Missouri and Lower Yellowstone rivers. Transactions of the American Fisheries Society 133:577-587.
Drobish MR. 2008. Pallid sturgeon population assessment program, Volume 1.3. U.S. Army Corps of Engineers, Omaha District, Yankton, South Dakota (see Supplemental Material, Reference S3, http://dx.doi.org/10.1996/022012JFWM-013.S5).

Dryer MP, Sandvol AJ. 1993. Recovery plan for the pallid sturgeon (Scaphirhynchus albus). U.S. Fish and Wildlife Service, Bismarck, North Dakota (see Supplemental Material, Reference S4, http://dx.doi.org/10.1996/022012JFWM-013.S6); also available: http://www.fws.gov/yellow stonerivercoordinator/pallid\%20recovery\%20plan.pdf (March 2013).

Edwards MS, Turner TF, Sharp ZD. 2002. Short and longterm effects of fixation and preservation on stable isotope values $\left({ }^{15} \mathrm{~N}\right.$ and $\left.\delta^{13} \mathrm{C}, \delta^{34} \mathrm{~S}\right)$ of fluid-preserved museum specimens. Copeia 4:1106-1112.

[ESA] US Endangered Species Act of 1973, as amended, Pub. L. No. 93-205, 87 Stat. 884 (Dec. 28, 1973). Available: http://www.fws.gov/endangered/esa-library/ pdf/ESAall.pdf (March 2013).

Everet SR, Scarnecchia DL, Power GJ. 2003. Comparison of age and growth of shovelnose sturgeon in the Missouri and Yellowstone Rivers. North American Journal of Fisheries Management 23:230-240.

Fuller RL, Mackay RJ. 1980. Feeding ecology of three species of Hydropsyche (Trichoptera: Hydropsyche) in southern Ontario. Canadian Journal of Zoology 58: 2239-2251.

Galster B, Wuellner MR, Graeb BDS. 2012. Walleye Sander vitreus and smallmouth bass Micropterus dolomieu interactions: an historic stable-isotope analysis approach. Journal of Fish Biology 81:135-147.

Gerrity PC, Guy CS, Gardner WM. 2006. Juvenile pallid sturgeon are piscivorous: a call for conserving native cyprinids. Transactions of the American Fisheries Society 135:604-609.

Gerrity PC, Guy CS, Gardner WM. 2008. Habitat use of juvenile pallid sturgeon and shovelnose sturgeon with implications for water-level management in a downstream reservoir. North American Journal of Fisheries Management 28:832-843.

Grohs KL, Klumb RA, Chipps SR, Wanner GA. 2009. Ontogenetic patterns in prey use by pallid sturgeon in the Missouri River, South Dakota and Nebraska. Journal of Applied Ichthyology 25:48-53.

Held JW. 1969. Some early summer foods of the shovelnose sturgeon in the Missouri River. Transactions of the American Fisheries Society 98:514-517.

Hoover JJ, George SG, Killgore KJ. 2007. Diet of shovelnose and pallid sturgeon in the free-flowing Mississippi River. Journal of Applied Ichthyology 23: 494-499.

Keenlyne KD. 1997. Life history and status of the shovelnose sturgeon, Scaphirhynchus platorynchus. Environmental Biology of Fishes 48:291-298.

Keenlyne KD, Jenkins LG. 1993. Age at sexual maturity of the pallid sturgeon. Transactions of the American Fisheries Society 122:393-396. 
Kelly B, Dempson JB, Power M. 2006. The effects of preservation on fish tissue stable isotope signatures. Journal of Fish Biology 69:1595-1611.

Kiljunen M, Grey J, Sinisalo T, Harrod C, Immonen H, Jones RI. 2006. A revised model for lipid-normalizing $\delta^{13} \mathrm{C}$ values from aquatic organisms, with implications for isotope mixing models. Journal of Applied Ecology 43:1213-1222.

Krentz S. (Missouri River Fish \& Wildlife Management Assistance). 2004. Scaphirhynchus albus. In: IUCN 2012. IUCN Red List of Threatened Species. Version 2012.1.

Michelsen K, Pedersen J, Christoffersen K, Jensen F. 1994. Ecological consequences of food partitioning for the fish population in a eutrophic lake. Hydrobiologia 291: 35-45.

Modde T, Schmulbach JC. 1977. Food and feeding behavior of the shovelnose sturgeon Scaphirhynchus platorynchus, in the unchannelized Missouri River, South Dakota. Transactions of the American Fisheries Society 106:602-608.

Overman NC, Parrish DL. 2001. Stable isotope composition of walleye: ${ }^{15} \mathrm{~N}$ accumulation with age and areaspecific differences in $\delta^{13} \mathrm{C}$. Canadian Journal of Fisheries and Aquatic Sciences 58:1252-1260.

Pegg MA, Pierce CL, Roy A. 2003. Hydrological alteration along the Missouri River Basin: a time series approach. Aquatic Sciences 65:63-72.

Peterson BJ, Fry B. 1987. Stable isotopes in ecosystem studies. Annual Review of Ecology and Systematics 18: 293-320.

Pflieger WL. 1997. The fishes of Missouri. Jefferson City: The Conservation Commission of the State of Missouri.

Post DM. 2002. Using stable isotopes to estimate trophic position: models, methods, and assumptions. Ecology 83:703-718.

Post DM, Layman CA, Arrington DA, Takimoto G, Quattrochi J, Montana CG. 2007. Getting to the fat of the matter: models, methods, and assumptions for dealing with lipids in stable isotope analysis. Oecologia 152:179-189.

Quist MC, Guy CS, Peg MA, Braaten PJ, Pierce CL, Travnichek VH. 2002. Potential influence of harvest on shovelnose sturgeon populations in the Missouri River system. North American Journal of Fisheries Management 22:537-549.

Rapp T, Shuman DA, Graeb BDS, Chipps SR, Peters EJ. 2011. Diet composition and feeding patterns of adult shovelnose sturgeons (Scaphirhynchus platorynchus) in the lower Platte River, Nebraska, USA. Journal of Applied Ichthyology 27:351-355.

Rounick JS, Winterbourn MJ, Graeme LL. 1982. Differential utilization of allochthonous and autochthonous inputs by aquatic invertebrates in some New Zealand streams: a stable carbon isotope study. Oikos 39:191-198.

SAS 2009. V. 9.2. SAS institute Inc. Cary, North Carolina. Schmidt SN, Vander Zanden MJ, Kitchell JF. 2009. Longterm food web change in Lake Superior. Canadian Journal of Fisheries and Aquatic Sciences 66: 2118-2129.
Shuman DA, Klumb RA, Wanner GA, Grohs KL. 2010. 2009 Annual report pallid sturgeon population assessment and associated fish community monitoring for the Missouri River: Segments 5 and 6. U.S. Fish and Wildlife Service, Great Plains Fish and Wildlife Conservation Office, Pierre, South Dakota. Prepared for the U.S. Army Corps of Engineers - Missouri River Recovery Program (see Supplemental Material, Reference S7, http://dx.doi.org/10.1996/022012-JFWM-013. S9); also available: http://www.fws.gov/greatplains fishandwildlife/publications.html (March 2013).

Sweeting CJ, Polunin NVC, Jennings S. 2004. Tissue and fixative dependent shifts of $\delta^{13} \mathrm{C}$ and $\delta^{15} \mathrm{~N}$ in preserved ecological material. Rapid Communications in Mass Spectrometry 18:2587-2592.

Sweeting CJ, Polunin NVC, Jennings S. 2006. Effects of chemical lipid extraction and arithmetic lipid correction on stable isotope ratios of fish tissues. Rapid Communications in Mass Spectrometry 20:595-601.

Takimoto G, Iwata T, Murakami M. 2002. Seasonal subsidy stabilizes food web dynamics: balance in a heterogeneous landscape. Ecological Research 17:433-439.

Tieszen LL, Boutton TW, Tesdahl KG, Slade NS. 1983. Fractionation and turnover of stable carbon isotopes in animal tissues: implications for $\delta C^{13}$ analysis of diet. Oecologia 57: 32-37.

Tripp SJ, Colombo RE, Garvey JE. 2009. Declining recruitment and growth of shovelnose sturgeon in the middle Mississippi River: implications for conservation. Transactions of the American Fisheries Society 138:416-422.

Trueman CN, McGill RAR, Guyard PH. 2005. The effect of growth rate on tissue-diet isotopic spacing in rapidly growing animals. An experimental study with Atlantic salmon (Salmo salar). Rapid Communications in Mass Spectrometry 19:3239-3247.

[USFWS] U.S. Fish and Wildlife Service. 1990. Endangered and threatened wildlife and plants determination of endangered status for the pallid sturgeon. Federal Register 55:36641-36647.

[USFWS] U.S. Fish and Wildlife Service. 2008. Pallid sturgeon (Scaphirhynchus albus) range-wide stocking and augmentation plan. Billings, Montana: U.S. Fish and Wildlife Service (see Supplemental Material, Reference S6, http://dx.doi.org/10.1996/022012-JFWM-013.S8).

[USFWS] U.S. Fish and Wildlife Service. 2010. Endangered and threatened wildlife and plants; threatened status for shovelnose sturgeon under the similarity of appearance provisions of the Endangered Species Act. Federal Register 75:53598-53605.

Vander Zanden MJ, Cabana F, Rasmussen JB. 1997. Comparing trophic position of freshwater littoral fish species using stable nitrogen isotopes $\left(\delta^{15} \mathrm{~N}\right)$ and literature dietary data. Canadian Journal of Fisheries and Aquatic Sciences. 54:1142-1158.

Vander Zanden MJ, Casselman JM, Rasmussen JB. 1999. Stable isotope evidence for the food web consequences of species invasions in lakes. Nature 401:464-466. 
Wanner GA, Shuman DA, Willis DW. 2007. Food habits of juvenile pallid sturgeon and adult shovel nose sturgeon in the Missouri River downstream of Fort Randall Dam, South Dakota. Journal of Freshwater Ecology 22:81-92.

Welker TL, Drobish MR (editors). 2010. Missouri River Standard Operating Procedures for Fish Sampling and Data Collection, Volume 1.5. U.S. Army Corps of Engineers, Omaha District, Yankton, South Dakota. (see Supplemental Material, Reference S5, http://dx. doi.org/10.1996/022012-JFWM-013.S7).

Yasuno N, Chiba Y, Shindo K, Fujimoto Y, Shimada T, Shikano S, Kikuchi E. 2012. Size-dependent ontogenetic diet shifts to piscivory documented from stable isotope analyses in an introduced population of largemouth bass. Environmental Biology of Fishes 93:255-266. 